\title{
粒状体のランダム・パッキングに関する一つの試み \\ ONE EXAMPLE OF TWO DIMENSIONAL RANDOM \\ PACKING OF SAND PARTICLES
}

\section{1.はじめに}

近年土を粒状体として取り扱う研究が多くなってき た。土の力学的特性の根本機構を解明するためには, 粒 子の集合体といら本来の姿に着目し, 各種の現象の内部 機構を微視的立場で把握して, それを巨視的な力学特性 と結びつけるためである。

日本においては, 最上の一連の研究が先導となり, 続 々と同種の研究が盛んとなっている。

土を粒状体として扱ら多くの既往研究を分類してみる と, 次のような 4 種となろら。

1. 実際に砂れきを扱った研究

2. 鉛散弹粒・ガラスビーズなどの球体を用いた研究

3. 鉛・アルミニウム・光弾性材料などの円柱を用い た 2 次元モデルによる研究

4. 抽象的モデルによるシミュレーション

われわれは, 粒子の性質を変化させることが容易, 今 まであまり試みられていないなどの理由から，4．の電 子計算機内での抽象的モデルによるランダム・パッキン グ・シミュレーションを試みることとした。

このランダム・パッキング問題は, 土木以外の分野, たとえば, 物理学, 化学工学, 治金などにおいては, 比 較的はやくからとり上げられており, Round と New$\operatorname{ton}^{1)}, V_{\text {old }}^{2)}$ らの研究がある。

\section{2. 既往の研究とわれわれのモデル}

すでに述べたように，粒状体のモデル化の試みがさま ざまな方法でなされ, その目的に応じて多くの成果が得 られてきている。本節では, コンピューターによる粒状 体のシミュレーションを取り扱ら観点から, 従来の研究

* 正 会 員 工博 東京大学助教授 地震研究所

** 学生会員東京大学大学院学生
伯 野 元 彦*.平 尾 寿 雄** By Motohiko Hakuno and Hisao Hirao

例をとり上げてみる。

モンテカルロ法によるランダムパッキングを作る方法 を分類すると, 次のようなものがあろら。

1. 棄却法 (rejection method)

2. 局所移動法 (method of local displacement)

3. 割込法 (intrusion method)

4. 落下法 (method of falling particles)

5. 成長法 (method of particle growth)

くわしい説明は省略するが，概略を説明すると，1.の 棄却法は確率諭的に最も近づきやすい方法である。これ は, 乱数により, 次々と粒子の位置を決定し, 粒子が重 なり合った場合は，棄却するといらものである。一次元 におけるランダムパッキングの問題はこの方法により取 り扱われている。2. の方法は, 粒子の中心を格子点に おき，それから一定の小さな範囲でランダムに動かすむ のである。3．はコヒレントな液体をシミュレーション するために, Round と Newtonによって用いられた方 法である。4.は粒子がある ポテンシャル 場をポテンシ ヤルの低いところに落ちる現象に対応するように作られ るものである。5. の成長法は鋳物の焼結における 金属 グレインの成長, 森林における植物の成長などのモデル で，ランダムの点を中心とし円を成長させるものであ る。

土を対象としてのランダムパッキングを考える上で は，4．の落下法が土の生成あるいは三軸試験における 試料の作成などを見ても，最も妥当な方法ではないかと 考えられる。本研究において村山朔郎ら の研究および 佐武正雄 $ら^{5)}$ の研究を参照したが, これらの研究におけ るパッキングの方法も基本的には落下法を用いたもので あろら。

村山らの方法は, 箱の中に粒状体を注ぎ込むとき, 個 々の粒子がおそらく粒子の落下地点付近の安定する位置 に順次積み上げられるであろらと仮定している。粒子の 抽出法にモンテカルロ法を採用し，パッキングを試みて 
いる。4 種の径の粒子を用い，乱数表をひいた值により 粒子を抽出している。粒子配置については, 最下段では 左から右に横につめて並べ, 右端に達すれば右から左 へ，その上の段で粒子の安定する位㯰に順次積み上げる ようにし, 再び左端に達すれば左から右へと順次パッキ ングを行なっている。粒子の材質としては抽象的な円， アルミ棒, 光弾性材料の丸棒を用い, 接点傾斜角の度数 分布, あるいは光弾性実験によるせん断時の粒子間伝達 力の実態把握を行なっている。

佐武らの方法は, パッキングを電子計算機で行なって いる。プログラムにより乱数を発生し, 粒子の組成割合 に応じた確率によって粒子の抽出を行なっている。粒子 配列の方法は, 重力が作用した場合を想定して, ある粒 子をつめるに当っては，できるだけ低位置に置くことに し, その条件に当てはまる位置がいくつかある場合に は, その内の最も端（左または右に固定）に近いものを とることにしている。このよらにして，あらかじめ定め たパッキング面に粒子がつまることができなくなるまで 続けている。具体的計算例 として 2 種類の円（径の比 19 : 12) についてパッキングを行なっている。また実験 として, 直径 $18 \mathrm{~mm}, 12 \mathrm{~mm}$ の 2 種の円筒（高さ約 10 $\mathrm{mm}$ )をそれぞれ塩化ビニールパイプ, アクリルパイプ より切り取り, 中に石膏をつめた粒子を用いて間げき率 の測定を行なっている。

以上の $2 つ の$ 例に共通していえることは，粒子配置の 決定にあたり，位置を一方の端から他端へと順次決定し ている点および，その位置が安定なものである点（具体

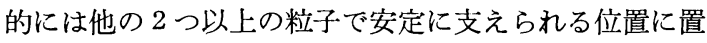
くこと)であろう。このような方法においては，粒子の 性質が粒子配列に影響するかどうかの比較は困難であろ う。また，準安定ともいえる状態を想定することも困難

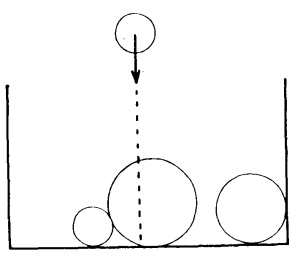

A

図-1 粒子の落下モデル
ではないかと思われる。

われわれは，図一1 に示す よらに，二次元的なモデルを 考え, 箱の中に任意の粒径分 布をもった円形断面が静かに 落下し，堆積していくという プロセスを採用した。そし て，粒子が落下し，他の粒子 または壁に接触し, 安定して停止するかどうかは, 通常 のクーロンの降伏条件が粒子間にも成立するとした。

\section{3. われわれの扱ったモデル}

\section{(1) 粒子の粒径分布}

プログラムに汎用性を持たせるために，粒径加積曲線
において加積率, 粒径とも に 0 から 1 の值を与え, 粒 径は, 粒子半径の最大值を 与えることにより種々の場 合に対応できるようにして ある。図示すると次のよ である。図一2 のよ5な粒 径加積曲線が与えられたと き,たて軸に一様乱数 $(A)$ を発生し，その值を加積曲 線に応じた值 $(B)$ に変換 する。次に半径の最大値

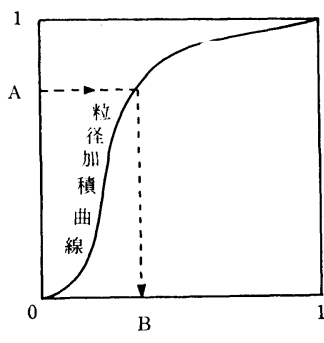

$B$ : 加積曲線により変換 した值

$R \mathrm{MAX}$ : 粒子半径の最大值 $R:$ 粒径

図一2 粒子徍の決定方法
$A:$ 発生した乱数

$R \mathrm{MAX}$ を $B$ に乗じその值を $R$ とする。このようにし て必要な個数だけの粒子の半径を決定する。

\section{（2）粒子位置の決定}

粒子形状は，取り扱いの簡単さから，円形としたた め, 粒子形状因子の粒子配列に及ぼす影響を考察するこ とは不可能となり, 粒子の物理化学的性質と粒状体の特 性の間の関連に的をしぼらざるを得なかった。すなわ ち, 粒子間摩擦角, 粘着力, 比重, ヤング率と粒径加積 曲線をパッキングのシミュレーションに導入することを 目的とした。粒子位置は，すでに存在する粒子とあらた に加わった粒子との相対的位置関係および接触した粒子 間での安定を検討することにより決定される。したがっ て, 次の過程で粒子位置を決定しる。

i ）粒子径の決定

ii）粒子の落下位置の決定

iii）落下地点真下付近の他粒子との接触

iv）接触位置での安定, 不安定の検討

v) 安定位置の決定

iv）の安定，不安定の検討においては, 種々の仮定を 行なっているので, 以下に多少詳しく述べる。

粒子を落下させた結果, 他の球と接触するが，このと き，以下に述べる規則にしたがって粒子の動きを追跡す る。

i ）粒子の形状を 円形（球形）としての パッキング を扱らが，他の球との位置決定にあたり，粒子のころが りを無視し，粒子の運動をすべりのみに限定する。この 仮定は, おそらく本研究における最も重要な仮定のひと つであろう。このような仮定の妥当性に関しては多くの 問題が残っているといえよう。にもかかわらず，このよ らな仮定を行なった理由は，主に次の 2 点によるのであ る。第一には, 円形 (球形) の粒子を扱ら場合, ころが りに抵抗するなんらかの力を導入することが困難である こと，第二には，実際の粒状体（砂，れきなど）におい て粒子の運動は主にすべりによると考えられることであ 


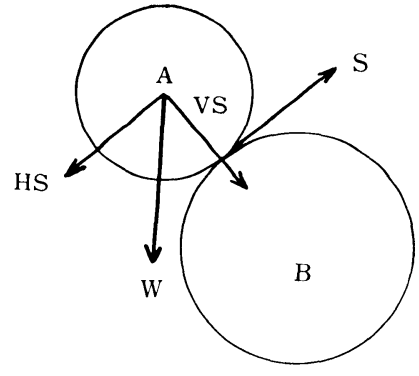

$W:$ 粒子Aの重量

$H S: W$ の接線方向の成分

$V S: W$ の垂線方向の成分

$S:$ 粒子間摩擦力および粘着力 に上る抵抗

図一3 粒子の安定検討 (a)

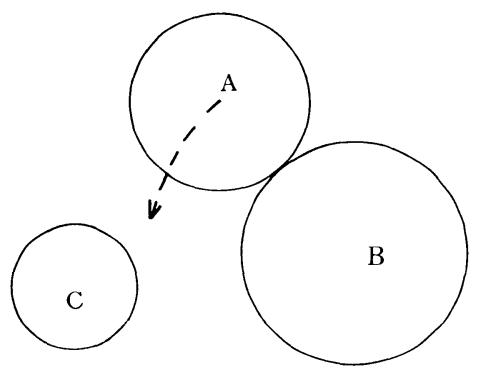

図-4 粒子の安定検討 (b)

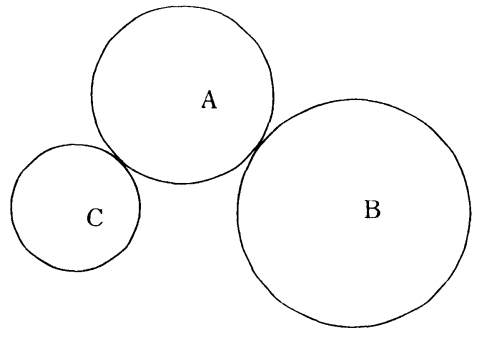

運動した結果他の球Cと接した。

図-5(a)

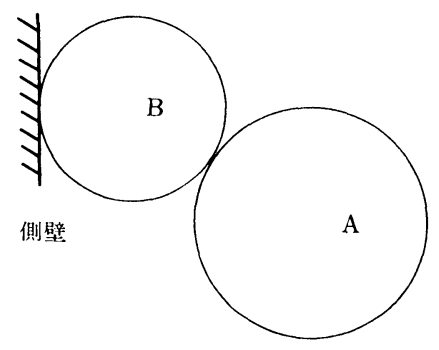

運動した結果側壁と接触した。

図-5 (b)

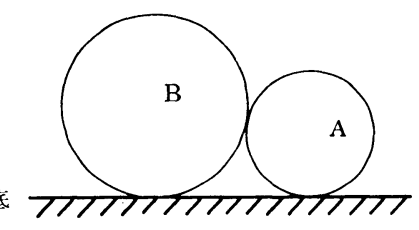

運動した結果底と接触した。

図-5(c)

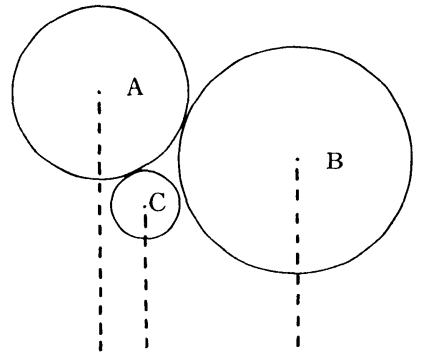

運動した結果他の球 $\mathrm{C}$ と接触したが, 球 $\mathrm{A}$

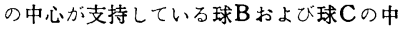
心のあいたかから外に出た。

…………不安定 この場合には, あらためて球 $\mathrm{A}$ と球Cのあ いだで,すべりの判定を行な5

図-5 (d)

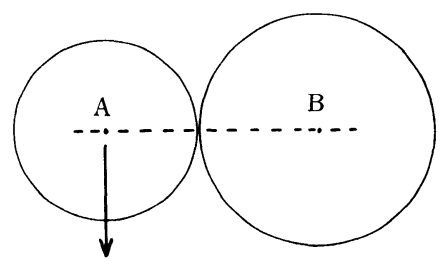

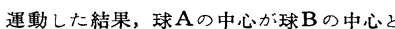
同じ高さになるまで，互に述べた 4 種類の どの場合にも当てはまらなかった。

$$
\text { ……………不安定 }
$$

この場合には，因の球 $\mathrm{A}$ の位㯰から，球を 落下させる。すなわち最初の状態にもとる。 図-5(e)
る。すべりのみを粒子の運動として考えることにより， 粒子間摩擦力および粘着力をパッキングに導入すること が可能となったわけである。

ii ）ここで相接する 2 粒子の力のつり合いを 図一3 のようにして取り扱ら。粒子間摩擦角および粘着力をそ れぞれ $\theta, C$ とすると, 図一-3における抵抗力 $S$ は

$$
S=V S \cdot \tan \theta+C
$$

として表わされる。HS および $S$ の值の比較から次の ような条件のときに粒子Aの運動を決定する。

$$
\begin{array}{ll}
H S>S & \text { 粒子A } \mathrm{A} \text { はずる。 } \\
H S<S & \text { 粒子A はこの状態で安定。 }
\end{array}
$$

$H S$ および $V S$ は $W$ から求められる。ゆえに粒子の 安定は, 粒子の径, 比重, 摩擦角, 粘着力から決定され るのである。このよらな判定を行なった結果, 安定であ ると判定されたとき, この粒子の位置はこの位置に決定 され, 以後粒子の移動はないものとして新たな粒子につ いての位置決定に移る。実際には, 次から次へと粒が上 から堆積した場合, 式 (1) のつり合い条件が満足され なくなるわけであるが, 本研究では, っり合い条件が以

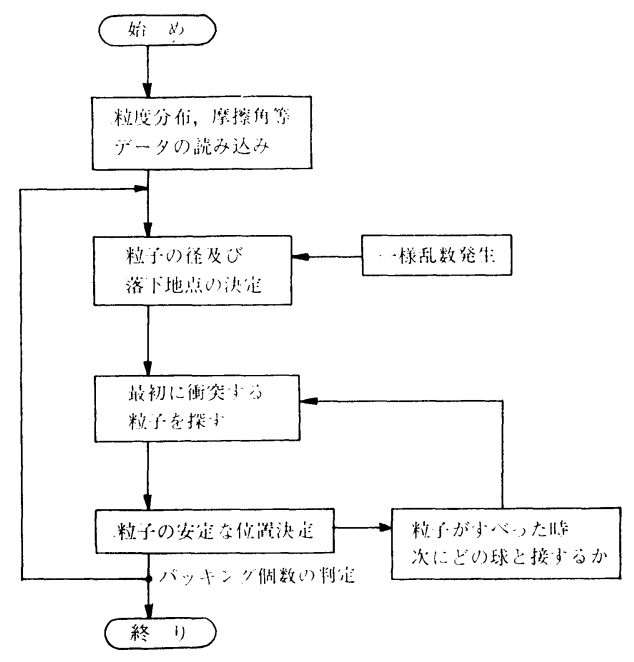

図一6 シミュレーション流れ図

後満足されなくなっても，粒子は崩壊しないとしてい る。この点は今後に残された問題である。

iii）上記の判定の 結果不安定であり粒子がすべると 

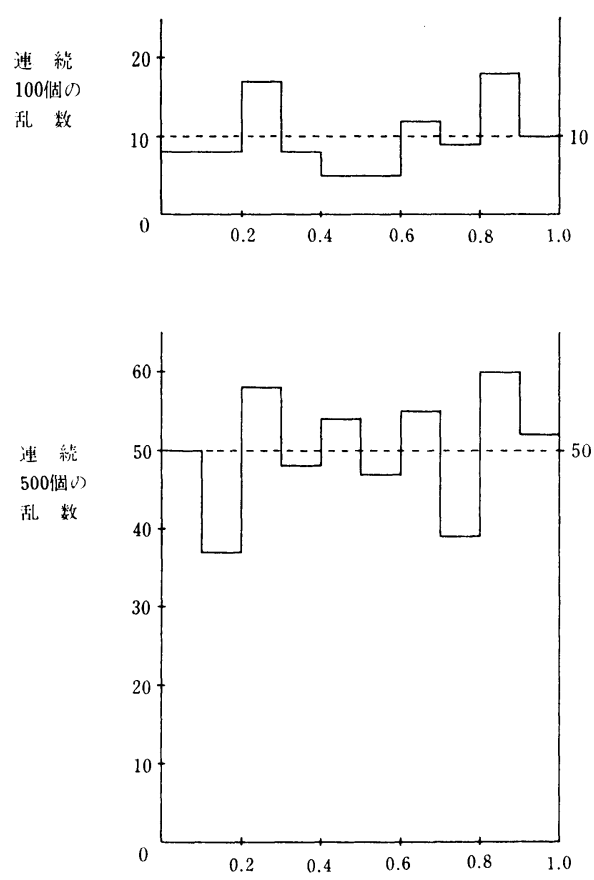

図-7 乱数の度数分布（計算機の組込関数）

判定されたとき, 次のような運動を考える。図一4のよ らに, 球 $\mathrm{B}$ の周囲にそって球 $\mathrm{A}$ をべらせるのである。 このような運動を粒子 A について考えたとき，粒子は 図一5 の場合のいずれかの状態となるであろう。以上の ようにして粒子の位置を次々と移動して行き安定と判定 される状態を求めた。

以上, この 数值実験の流れ図を示寸と図一6のよう になる。

\section{（3） 発生した乱数の性質}

計算機中で一様乱数を計算し，それを使用したわけで あるが，その統計的性質は，シミュレーション結果にも 影響することもあると思いチェックしてみたところ，図 一7に示すような結果が得られた。ほぼ一様と見なせる であろら。

\section{4. 数值実験結果とその考察}

以上述べた方法により，実際にパッキングを行なった 結果を述べる。入力データとして次表のような值を用い た。

以上の数值を適宜組合せて合計 7 種のパッキングを行 なった。

粒径加積曲線は, 本研究においては, 粒径と粒子数百 分率で与えてある。 3 種のタイプ $\mathrm{S}, \mathrm{M}, \mathrm{G}$ を図示する と図一8 (a),(b),(c) のよらになる。ここで $\mathrm{S}$ タイプ
とは同一粒径の粒子 のパッキングであ り， M タイプは村 山らの研究で用いら れた粒度分布と類似 するものであり, G タイプは, まったく ランダムに粒子径を 決定するタイプであ る。

$$
\text { このような } 3 \text { つの }
$$

\begin{tabular}{|c|c|}
\hline 粒 子 数 & 100 個 \\
\hline 粒径加積曲線 & $\mathrm{S}, \mathrm{M}, \mathrm{G}$ の 3 種 \\
\hline \multirow[t]{3}{*}{ 最 大 粒 径 } & $\mathrm{S}$ タイプ 0.04 \\
\hline & Mタイプ 0.15 \\
\hline & Gタイプ 0.08 \\
\hline \multirow[t]{2}{*}{ 粒子間摩擦角 } & 0.0 ラジアン \\
\hline & 0.4 ラジアン \\
\hline \multirow[t]{2}{*}{ 粘 着 力 } & 0.0 \\
\hline & 0.003 \\
\hline 比 & 1.0 \\
\hline
\end{tabular}

タイプが実際の砂あるいは れきの粒度分布をよく表現 しているとは考えられな い。ここでは,このような 3つのタイプによりどのよ らな差があらわれるかを見 たかったためである。必要 であれば任意の粒度分布を 与えることによりパッキン グを行なえばよいのであ る。同様に粒子間摩擦角, 粘着力, 比重, 最大粒径, 粒子数などすべて任意の值 を与えることによりどのよ らなパッキングも可能であ ることが, コンピェーター によるランダムパッキング の特長なのである。

次に, 数值実験結果の数 例を示し考察を加えよう。

図一9（a）:粒径が均一 で, しかも摩擦も, 粘着力 もないという理想的な場合 であって, 最も密につまる 配列である。村山らの結果 と類似している。

$$
\text { 図一9 (b), (c) : 同じく }
$$

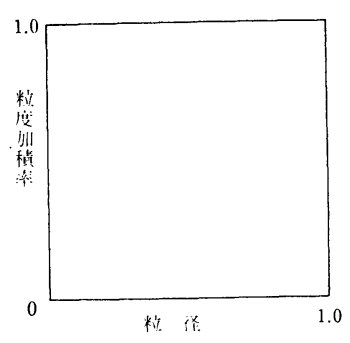

図一8 (a) S タイプ

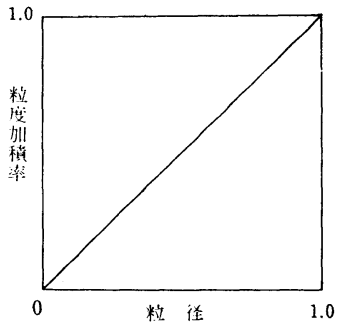

図一8 (b) G タイプ

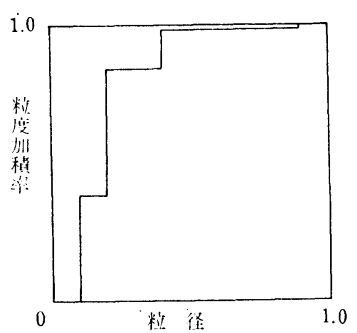

図一8(c) M タイプ 粒度均一で, 摩擦または, 粘着力の働らく場 合である が，摩擦と粘着力の間に効果の差はないよらに見える。 しかも，アクロバット的な構造が見受けられるが，これ は後述するように, 粒子の安定位置をいったん決めた後 は，その上に落下した粒子の重みに耐えかねて，崩壊す るという現象を考慮していないためと思われる。

図一9(d): 粒径, 大, 中, 小の三種が混合したタイプ のパッキングであるが，この場合には，教科書どおり， 大径粒子間に中, 小粒子がつまって, 密度をたかめてい 

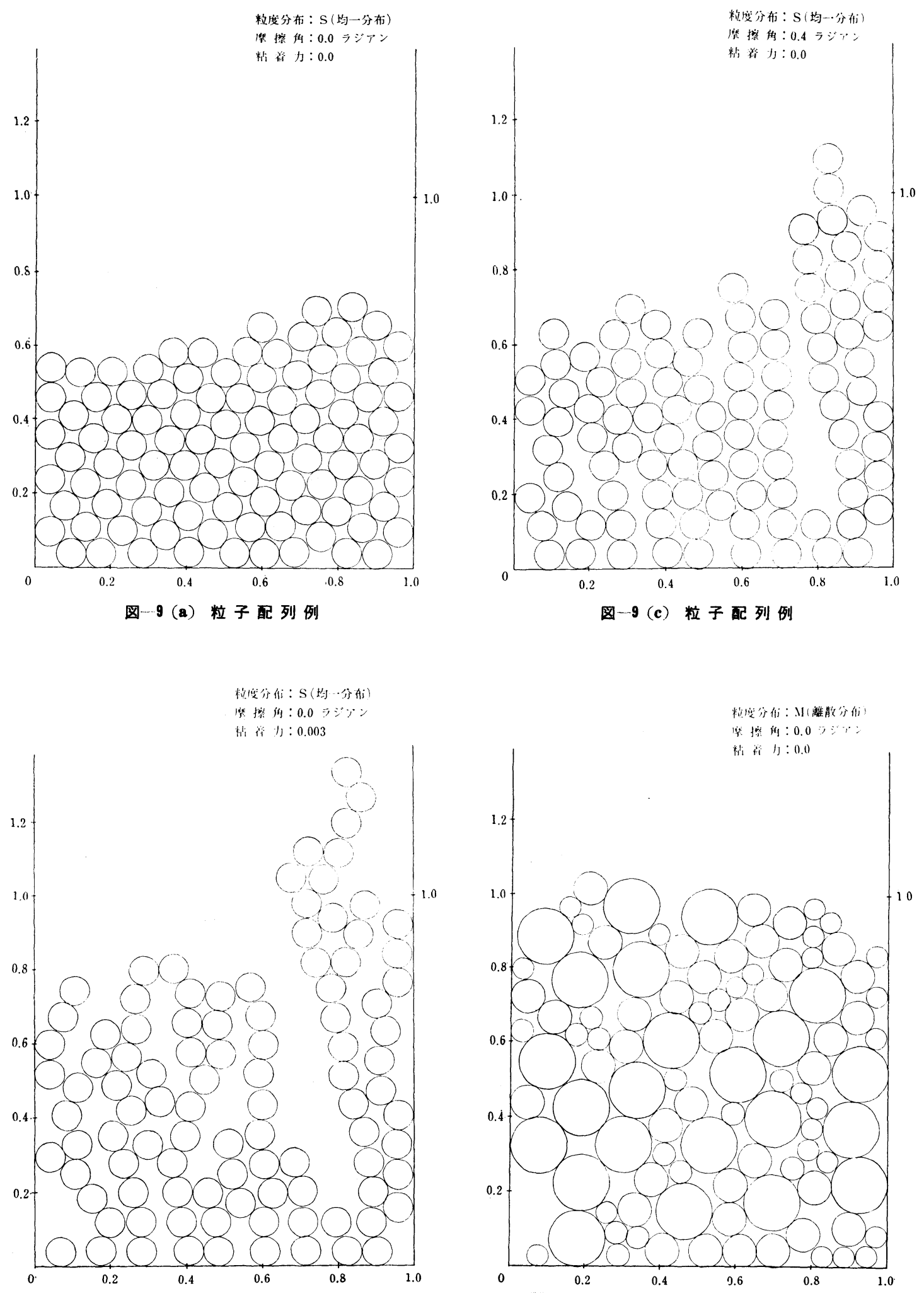

図一9（b）粒子配列例

図一（d) 粒子配列 例 


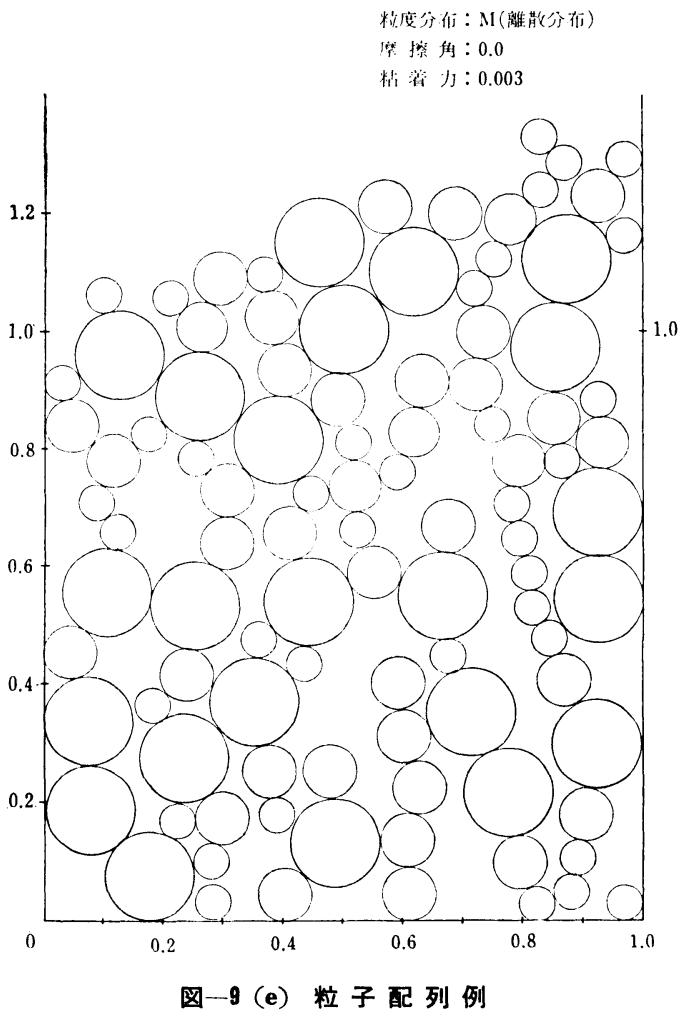

粘辟分有：以(離散分们) 摩摖角: 0.4 ラジフン 粘藉力: 0.0

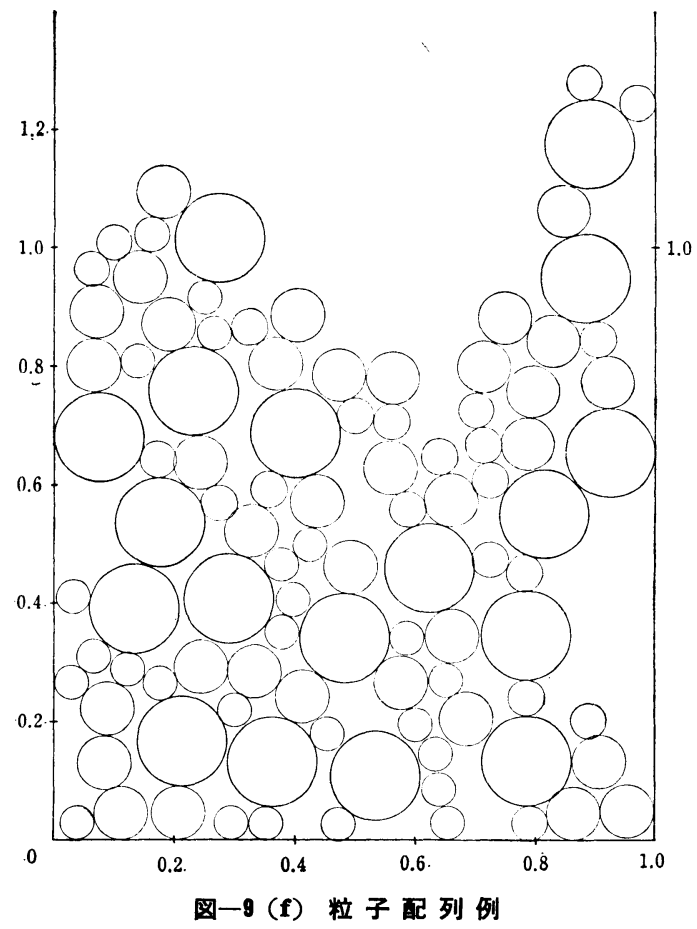

粘度分有：G(一㥞分有)

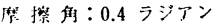

粘养力: 0.0

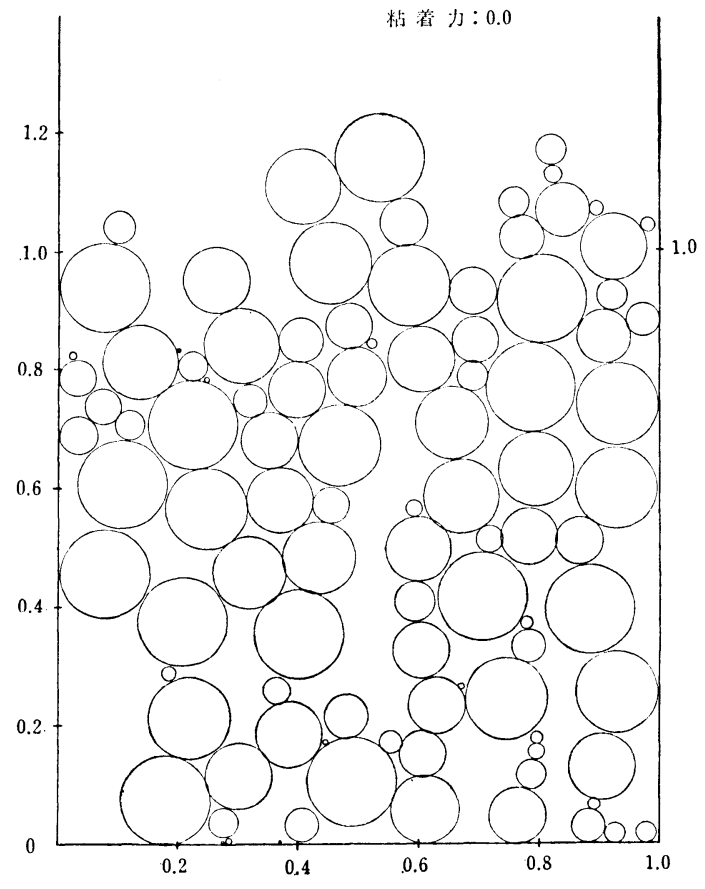

図一9（g）粒子配 列 例

\section{ることがわかる。}

図一9(e),(f)：それぞれ摩擦, 粘着力のみが, 作用し た場合であるが,これらは, 粘土の微構造として得られ ているものに似ている場合もある。

図一9 $(\mathrm{g})$ : 粒度が一様に 分布している場合であるが， やはり, 密度が比較的高いつまり方をしているようであ 万。

\section{5. パッキング結果の考察}

\section{（1）安息角の検討}

パッキングの際, 粒子をある限られた位置から落下さ せ，パッキングの状態を調べることにより粒子間摩擦角 と安息角との刘応がつかないであろらかとの考えから実 際にそのよらなパッキングを行なってみた。ある程度予 想されたことではあるが, 結果はさんたんたるものであ った。安息角が実際よりも非常に大きく出たのである。

この原因の最大のものは, 粒子位置決定をある粒子と その粒子の接している粒子との間での安定の判定のみに よった点である。つまり, 図一10(a),(b) のよ5な 2 種 類の場合ともに安定と判断されることによるのである。 図一10(a)において粒子A A゙安定と判定されたとき， 


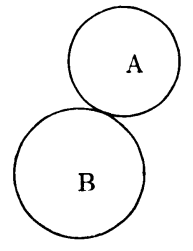

図-10(a)

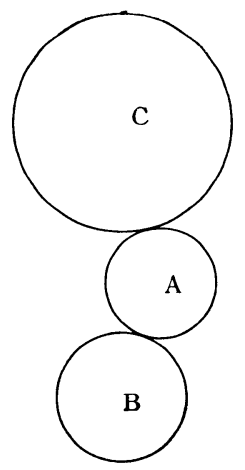

図-10(b)

後に 図一10 (b) の上うに新たに粒子C が接触して も, 粒子Aの安定はまったく不動のものとしているこ とによるのである。実際には, 図一10(b) のような場 合, $\mathrm{A}$ と B との間での安定条件は満されなくなるであ ろう。したがって, 粒子Cの位置も変化するのであ る。

以上の条件をプログラムに取りくむことが今後の最 大の課題となるであろう。

\section{（2）粒状体の内部応力の推定}

村山らの粒状体のシミュレーションにおいては, 光 弾性材料の丸棒を用いたせん断試験から, 粒状体内部 の応力を推定しようと試みている。本研究においては次 のような方法により，まったくのモデル化によって応力 の推定を試みた。すなわち, 粒子が他の粒子と接触して いるとき, 2 粒子の中心間に 2 つの粒子の半径の和を長 さとする一様断面の部材が存在するものと想定し, 粒状 体を骨組構造物に置きかえることにより応力の推定を行 なってみた。

具体的には, 図一11 のような構造の変更を行なうわ けである。このような変換を考えた理由として, 粒子の 接触点において伝達される垂直忘力, せん断などが骨組 構造物においてあらわれる軸力，モーメントなどと対応 しらるのではないかと考えたからである。

さて，骨組構造物に置換えを行なら場合には，骨組部 材の断面, 弾性係数が粒子間のばね係数と等しくなるよ

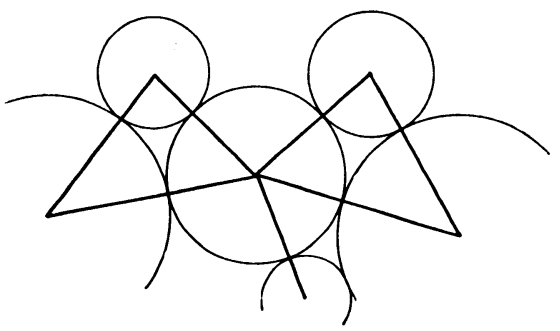

図一11粒体構造の骨組篗造への変換
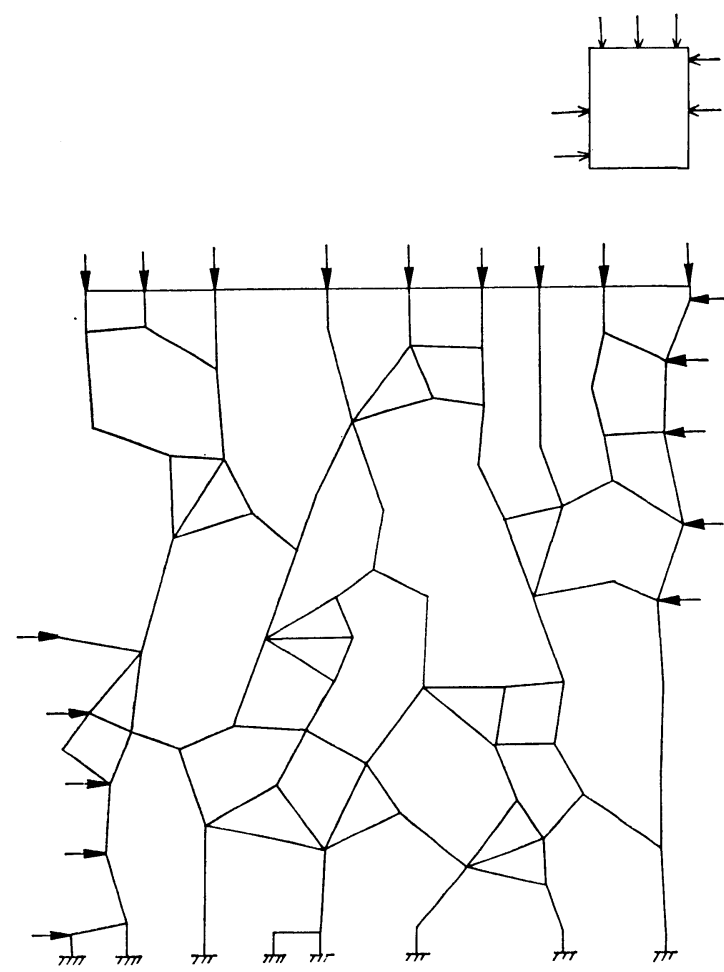

図一12 パッキングモデルの骨組構造への変換

らに決定した。すなわち, Hertz の理論により ${ }^{6)}$, 半径 $R$ の球が平面に接し, 互いに $P$ といら圧力で圧しつけ られた場合, 球の中心の相対変位 $\alpha$ と $P$ との関係は,

$$
\begin{gathered}
K=\frac{d P}{d \alpha}=2 \mu a /(1-\mu) \\
\text { こに, } a=[3(1-\nu) P R / 8 \mu]^{1 / 3}
\end{gathered}
$$

$\nu, \mu$ はポアソン比とせん断弹性係数である。 このように $P$ と $\alpha$ の関倸は比例関係になく, ばね係数 が圧力 $P$ によって変わるといら複雑な関係である。

同様にせん断力 $S$ を受けた場合, 変形 $\delta$ との間には 次のような関係がある。

$$
L=\frac{d S}{d \delta}=4 \mu a /(2-\mu)
$$

本研究では, 各球間の $P$ は一定值と仮定して, 球の 直応力に対するばね係数 $K$ と摩擦力に対するばね係数 $L$ を定め, それを部材の直力に対するばね係数, 部材の 両端が埋め込みの場合のせん断変形から導出したせん断 ばね俰数と等しくなるように, 弾性係数, 断面形状を定 めた。

具体的なモデルとしての構造は, 先にパッキングを行 なった粒度分布 $\mathrm{M}$ タイプの摩擦角 0.4 ラジアン, 粘着 力0の場合のパッキングモデルについて骨組で置きかえ たものを用いた。その骨組は 図一12 のよ5である。

こうして作成した構造に同図に示したような上下なら 


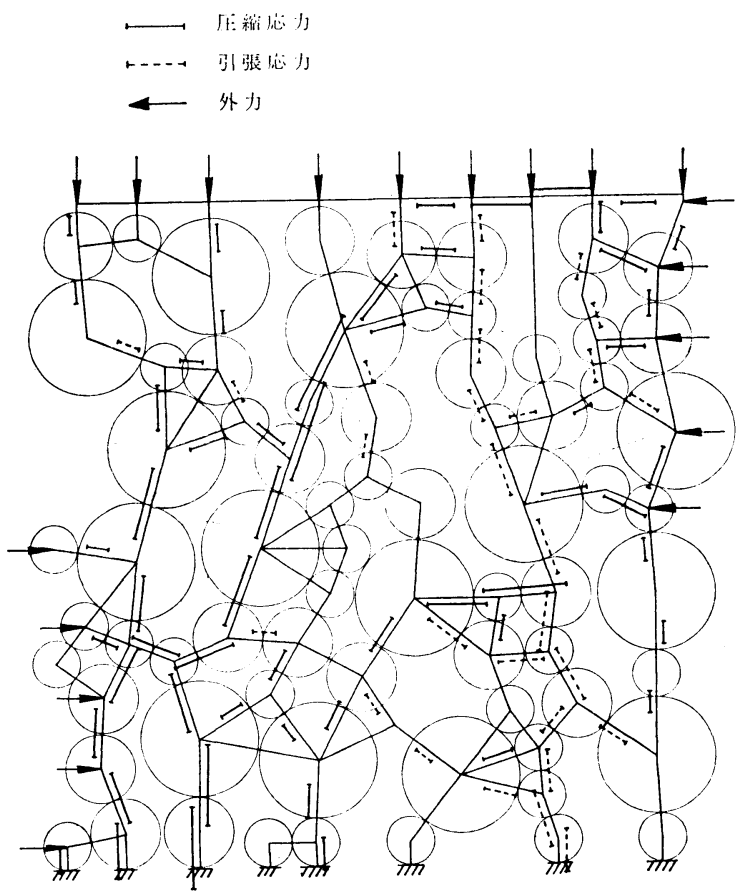

図一13 粒子間に鹤く直応力

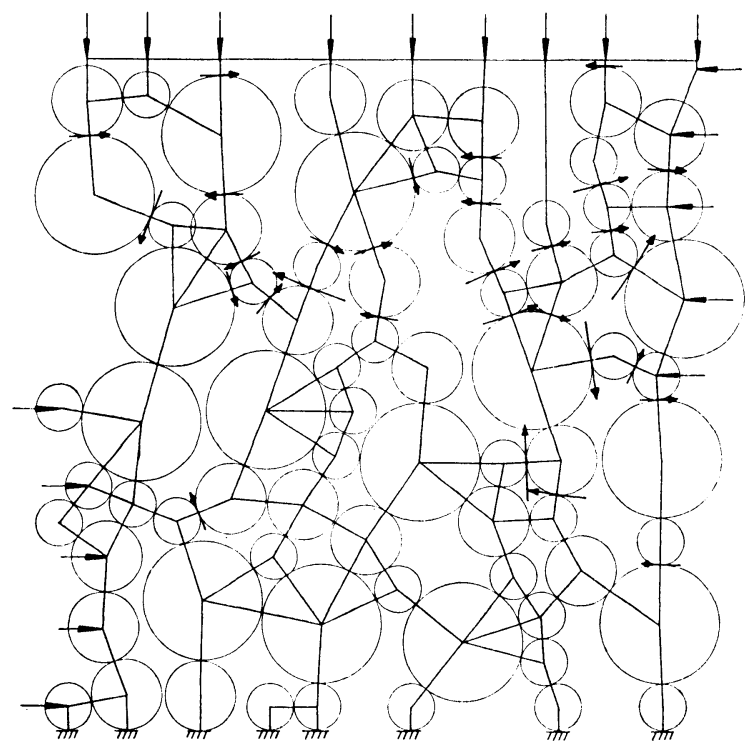

図一14 粒子間に钭くせん断力

びに水平方向に荷重を加え，そのときの応力をマトリッ クス法を用いて求めた。その結果を 図一13,14 に示し てある。この図には力の記入されていない個所もある が，これは図が見ゔらくなることを避けるため，ある程 度以下の大きさの力は記入しなかったためである。

この結果を見ると, 図一13 の直応力に関しては, 右 下隅から, 左上へかけて, 引張り応力を生じていること
が多く, 左下隅から右上へかけての方向では, 圧縮応 力を生じていることが多い。個々の応力にはかなりの ばらつきがあるが全体として見た場合には，常識的な 結果といえよう。

せん断応力（図一14）では，水平外力を加えている 右上部と，それに次いで，左上部に大きいせん断力が 多くの粒子間に作用している。そして，個々の粒子に ついてみると，粒子を回転させようとする力が粒子表 面の 2 か所，なかには 3 か所に働いている場合もあっ て，実際にすべりを生じる場合には，粒子が回転を起 しながらすべることもあることを示唆していて興味樑 い。

\section{（3）間げき比について}

間げき比については, 同様のシミュレーションによ って, 村山らは 4 種の径の粒子について 0.28 を, 佐 武は， 2 種の径の粒子について，実験を行ない，0.22 を得ているが，われわれの場合，3 種の粒径の粒子を 混合し, 摩擦係数を 2 種に変えて 表一1 のような結 果を得た。摩擦の ない場合には，粒 度分布にはあまり 関係せず, 間げき 比はだいたい，村 山らの值と似てい

\begin{tabular}{rrr|c|c}
\multicolumn{6}{c|}{ 表一1 } \\
\hline 粒 & 子 & 数 & 比 & \multicolumn{2}{|c}{ 間げき比 } \\
\hline $0.04 \phi$ & $0.08 \phi$ & $0.16 \phi$ & $\theta=0$ & $\theta=0.4$ \\
0 & 100 & 0 & 0.27 & 0.47 \\
40 & 40 & 20 & 0.31 & 0.36 \\
20 & 30 & 50 & 0.27 & \\
10 & 20 & 70 & 0.27 &
\end{tabular}
るが,これは村山 らのパッキングの方法を考えれば，それが，とりもな おさず最も密につめていく方法であり, その結果が, 摩擦のない場合と，ほほ等しいといらことは首肯でき よう。摩擦のある場合には，もちろん，間げき比は増 大していく。ただ，その増加のしかたは，粒子の安定 条件を第 1 段階でしか考えていないため，大きめに山 ていると思われる。

\section{6.むすび}

電算機中において，任意粓度分布をもつ粒子を発生 させ，箱中に落下させ，粒子間に働らく，摩擦力，粘 着力のみによって定まる降伏条件の下で，どのような 粒状構造が生じるかを調べ,さらに，その構造に外力 を加えた場合の応力状態を剛トラスとして解いてみた。 この試みにより次のことがらが知られたと思う。

（1）粒子間摩擦係数または, 粘着力が大きくなる と，当然のことながら，空げきが増える。ただ，本研究 では粒子間の安定は，その粒子が落下した時のみにチェ ックするだけであるので，粒子がほぼ直立して成長する といら場合もあった。これは，今後に残された問題であ 
る。

（2）摩擦倸数と粘着力がない場合には，最密と思わ れる粒状体構造を形成した。

（3）摩擦係数, 粘着力が小さいかない場合には, 大 きい粒子の間の空げきを小さい粒子が埋めて, 密な組織 となっていた。

（4）この粒状体に，外力をかけたときの粒子間に働 らく応力は，連続体として見た場合には，当然のことな がらばらつきが多すぎる感じではあるが，全体としての 傾问は，常識的なものであった。粒子に回転を起こさせ るようなせん断力が働いている場合も認められた。

（5）本研究では粒子の累積による安定性の変化が無 視されているため, 摩擦係数, 粘着力が非常に小さい場 合にしか適当な結果を与えないよ5に思われた。

（6）今後の課題としては, さらに進んで粒状体とし ての破壊，すなわち，粒子間のすべりをこのシミュレー
ションによって，取り扱うことである。

本研究に当っては, 東京大学土木工学科 石原研而助 教授の適切なアドバイスを頂いたことを感謝致します。

\section{参考文 献}

1) Round and Newton: Random packing of equal spheres on a plane surface, Nature 1963

2) Vold, M.J. : Sediment volume and structure in suspensions of anisometric particles, J. Chem. Phys. 1962

3）桶口伊佐夫：粒子統計比ける二,三の研究，統計数理研 究所彙報 12 巻 1 号 (1964)

4）村山朔郎・松岡 元：2次元モデルによる粒状体のせん断 現象の微視的考察, 京都大学防災研究所年報第 13 号 B

5）佐武正雄 他：電子計算機によるパッキングのシミュレ 一ションについて, 土木学会東北支部技術研究発表会講 演概要, 昭 46 年

6) Timoshenko and Goodier : Theory of Elasticity, pp. 372 377 (1951) McGraw-Hill

(1972. 8. 7 . 受 付 